П.П. Ковель ${ }^{1}$, О.В. Карпенко ${ }^{1}$, М.С. Стрєла ${ }^{1}$

${ }^{1}$ Державний науково-дослідний інститут авіаиії, Київ

\title{
АНАЛІЗ ТЕМПІВ ВИЧЕРПАННЯ РЕСУРСНИХ ПОКАЗНИКІВ СИЛОВИХ ЕЛЕМЕНТІВ ПЛАНЕРА ЛІТАКІВ ТИПУ ИЛ-76 ЗА ФАКТИЧНИМ НАВАНТАЖЕННЯМ СИЛОВОЇ КОНСТРУКЦЇ̈
}

В статті наведено розроблену методику збору та обробки інформації щцодо рівня навантаження силових елементів конструкції планера військово-транспортних літаків Ил-76 в процесі експлуатації з метою визначення кількісної оцінки їх фактичного залишкового ресурсу. Розроблена методика дозволить удосконалити систему обліку витрат ресурсу планера $і$ використовувати отримані з ї допомогою результати для коригування встановлених показників ресурсу планера при реалізації іï стратегіï експлуатації за технічним станом.

Ключові слова: втомна міцність, відносне пошкодження при втомі, еквівалент витрати ресурсу, коефічієнт витрати ресурсу, експлуатація за технічним станом.

\section{Вступ}

Постановка проблеми. У теперішній час $\mathrm{y}$ державній авіації України винятково актуальним стало питання про подальший розвиток вітчизняної нормативно-технічної та методичної бази в частині збереження льотної придатності повітряних суден як експлуатованих, так і новостворених (придбаних). При вирішенні цієї проблеми потрібні нові підходи, залучення до досліджень фахівців різних організацій та підприємств.

Наразі основним методом підтримання льотної придатності повітряних суден у авіації Повітряних Сил (ПС) Збройних Сил України є продовження міжремонтних i призначених показників при виконанні робіт 3 відновлення справності у експлуатуючих частинах та при виконанні контрольно-відновлювальних робіт на авіаремонтних підприємствах. Такий підхід забезпечив підтримання справності та льотної придатності значного парку ПС при економічно обгрунтованих фінансових витратах.

Наразі при проєктуванні та випробуванні експлуатуючих повітряних суден на підприємствахвиробниках зазвичай використовувались такі методи моделювання та розрахунку ресурсних показників, які були сучасні на стан $60-x$ років минулого століття. Ці методи мали досить великий розкид в результатах, тому при остаточному призначенні ресурсних показників закладався великий коефіцієнт безпеки, який зазвичай надавав значну безпеку польотів, та не повну виробітку ресурсного потенціалу. Сучасний стан розвитку методів математичного моделювання із застосуванням комп'ютерів значно розширив можливості більш точного визначення ресурсних показників.

Зараз в авіації ПС є проблема в індивідуальних (подетальних) розрахунках довговічності елементів основної силової конструкції за межами призначених показників, зокрема, наприклад, крила літака типу Ил-76, оскільки парк зазначеного типу повітряних суден вже наближається до вичерпання призначеного ресурсу. Такі дослідження дають можливість обгрунтовано підійти до вирішення питання про забезпечення експлуатації літака за межами призначених показників при його економічній доцільності.

Аналіз останніх досліджень і публікацій. Ресурсні розрахунки проводяться 3 застосуванням методів теорії ймовірності $[1 \ldots 8 ; 11 \mathrm{c.} 71$; 12 , с. 56...72], тому результат розрахунків - а саме ресурс конструкції - $є$ випадковою величиною Т, 3 якою слід поводитися за законами теорії ймовірності, тобто уявляти, що неможливо приписати ресурсу конкретне (детерміноване) значення, а слід вести мову про інтервал значень $T_{\text {мін }} \ldots T_{\text {мах }}$, в якому 3 певною ймовірністю $P$ знаходиться дійсне значення цієї величини.

Можливо вести мову про математичне очікування $T_{c p}$ цього показника $\mathrm{i}$ про розкид значень відносно цього середнього показника, який оцінюється середнім квадратичним відхиленням $\sigma_{T}$.

Ліва границя інтервалу $T_{\text {мін } \ldots T_{\text {мах }}}$ розрахована за умовою $T_{\text {мін }}=T_{c p}-3 \sigma_{T}$, одержала назву безпечного ресурсу $T_{\text {без }}$. 
Ймовірність втомного пошкодження конструкції аварійного характеру в межах цього показника не перевищує 0,001 , що в світовій практиці вважається нормою.

Оскільки криві втомної міцності для більшості матеріалів мають майже лінійний характер в логарифмічній шкалі [10, с. 79], розрахунки ресурсу $T$ ведуть також з використанням логарифмічної шкали. Більш того, при цій шкалі розподіл випадкової величини $\lg _{T}$ підпорядковується нормальному закону розподілу, найбільш поширеному у розрахунковій практиці.

Тож, маючи криву втомної міцності елемента конструкції, характеристику іiі розкиду і спектр експлуатаційних навантажень, можливо проводити ресурсні розрахунки методами теорії ймовірності.

Проте розкид характеристик втомної міцності не $є$ єдиною причиною розкиду значень ресурсних показників, маються ще й інші чинники. Наприклад, навантаження літака в польоті і на землі теж мають суттєво випадковий характер, обумовлений турбулентністю атмосфери, маневрування літака згідно з манерою пілотування кожного окремого льотчика із поставленим польотним завданням, станом поверхні аеродрому, тощо.

Прийнятий у роботі метод розрахунку ресурсу [6...8] містить у собі перевірену багаторічною практикою методику розрахунку ресурсу, засновану на лінійній гіпотезі підсумовування втомних пошкоджень, використанні наявних характеристик втомної міцності конструкції (це може бути крива втомної міцності матеріалу конструкції 3 визначеним коефіцієнтом концентрації напружень або реальна крива втомної міцності цієї конструкції, отриманої експериментальним шляхом), поточної (3 використанням даних бортових записів параметрів польоту) або статистичної інформації про повторні навантаження, що діють на конструкцію або іiі елементи протягом життєвого циклу.

Врахування додаткової інформації, тобто всього того, що не піддається точному розрахунку, пропонується здійснювати через середні значення (математичні очікування), відповідних параметрів і внесення в розрахунки певних коригуючих коефіцієнтів.

Оскільки в такій постановці питання розрахунки можливо проводити тільки 3 використанням ЕОМ, авторами розроблене відповідне програмне забезпечення.

Мета статті - обгрунтування можливості експлуатації старіючого парку літаків типу Ил-76 шляхом збільшення значень ресурсних показників при їх експлуатації за технічним станом.

\section{Виклад основного матеріалу}

Відповідно до вимог проведення ресурсних досліджень потрібно мати матеріали об'єктивного контролю (записів бортових реєстраторів) щодо наявних навантажень планера літаків типу Ил-76, що перебувають у складі авіації ПС Збройних Сил України. Тому відібрано записи бортових ресстраторів параметрів польоту (БУР-4) за $2020 \ldots 2021$ pр. загальним обсягом понад 100 годин польоту з військових частин ПС, що експлуатують літаки типу Ил-76МД, для подальшої обробки.

Формування масиву вхідних даних починається 3 відбору записів бортових реєстраторів БУР-4 та проведення первісної обробки даних параметрів польоту літаків типу Ил-76 [3, с. 146; 4, с. 248]. Обробка відібраних записів параметрів польотів літаків виконувалось за допомогою програмно-обчислювального комплексу "МОНСТР".

Вибрані записи оброблялись та заносились до файлів програми Microsoft Office Excel у вигляді таблиці 1. Сигналограма після відбору записів бортових реєстраторів БУР-4 має вигляд, наведений на рис. 1.

Для відбору необхідних даних потрібно обробити окремо циклограми висоти польоту, приладової швидкості та вертикального перевантаження. Після обробки цих даних формуються відповідні залежності у вигляді рисунків 2...4. Вертикальне перевантаження у центрі мас літака, впливає на навантаження силових елементів планера літака. Зміна маси палива за часом польоту приводить до зміни в цілому маси літака $\mathrm{i}$, як наслідок, до зміни навантаження силової конструкції літака. Під час зльоту та посадки необхідно враховувати вертикальні, повздовжні та бокові перевантаження, які пов'язані з навантаженням, в першу чергу, силових елементів шасі літака.

Відбір записів польотів проводився випадковим чином, але так, щоб до розгляду попали всі літаки частини i всі льотчики, які здійснювали польоти у 2020 та 2021 роках.

Розшифровка відібраних записів виконана у програмі EXCEL і містить послідовне зазначення даних перевантаження стовпчиком i запис $\mathrm{y}$ окремий файл у форматі *.txt для кожного польотного завдання.

Таблиця 1

Відомості про політ льотчика

\begin{tabular}{|c|c|c|c|c|c|}
\hline \multicolumn{6}{|c|}{ Дата: 05.06.2020 } \\
\hline \multicolumn{6}{|c|}{ Літак Ил-76МД № 76699(0063471131) } \\
\hline \multicolumn{6}{|c|}{ Льотчик: } \\
\hline \multicolumn{6}{|c|}{ Наявність грузів: } \\
\hline \multicolumn{6}{|c|}{ Злітна масса: 160000 кг } \\
\hline \multicolumn{6}{|c|}{ Посадкова масса: 125000 кг } \\
\hline \multicolumn{6}{|c|}{ Час польоту, год:хв:сек 4:49:08 } \\
\hline $\begin{array}{c}\text { № } \\
\text { П/П }\end{array}$ & $\begin{array}{c}\tau, \\
\text { год:хв:с }\end{array}$ & $\begin{array}{c}\text { Нбар, } \\
\text { м }\end{array}$ & $\begin{array}{c}\text { Vпр, } \\
\text { км/год }\end{array}$ & GT, кг & Примітка \\
\hline 1 & 0:00:00 & 0 & 0 & 160000 & запуск СУ \\
\hline 2 & $0: 16: 01$ & 0 & 259 & & зліт \\
\hline 3 & 4:44:06 & 0 & 211 & 125000 & посадка \\
\hline & 4:49:08 & 0 & 0 & & $\begin{array}{c}\text { вимкнення } \\
\text { АД }\end{array}$ \\
\hline
\end{tabular}

Джерело: розроблено авторами. 


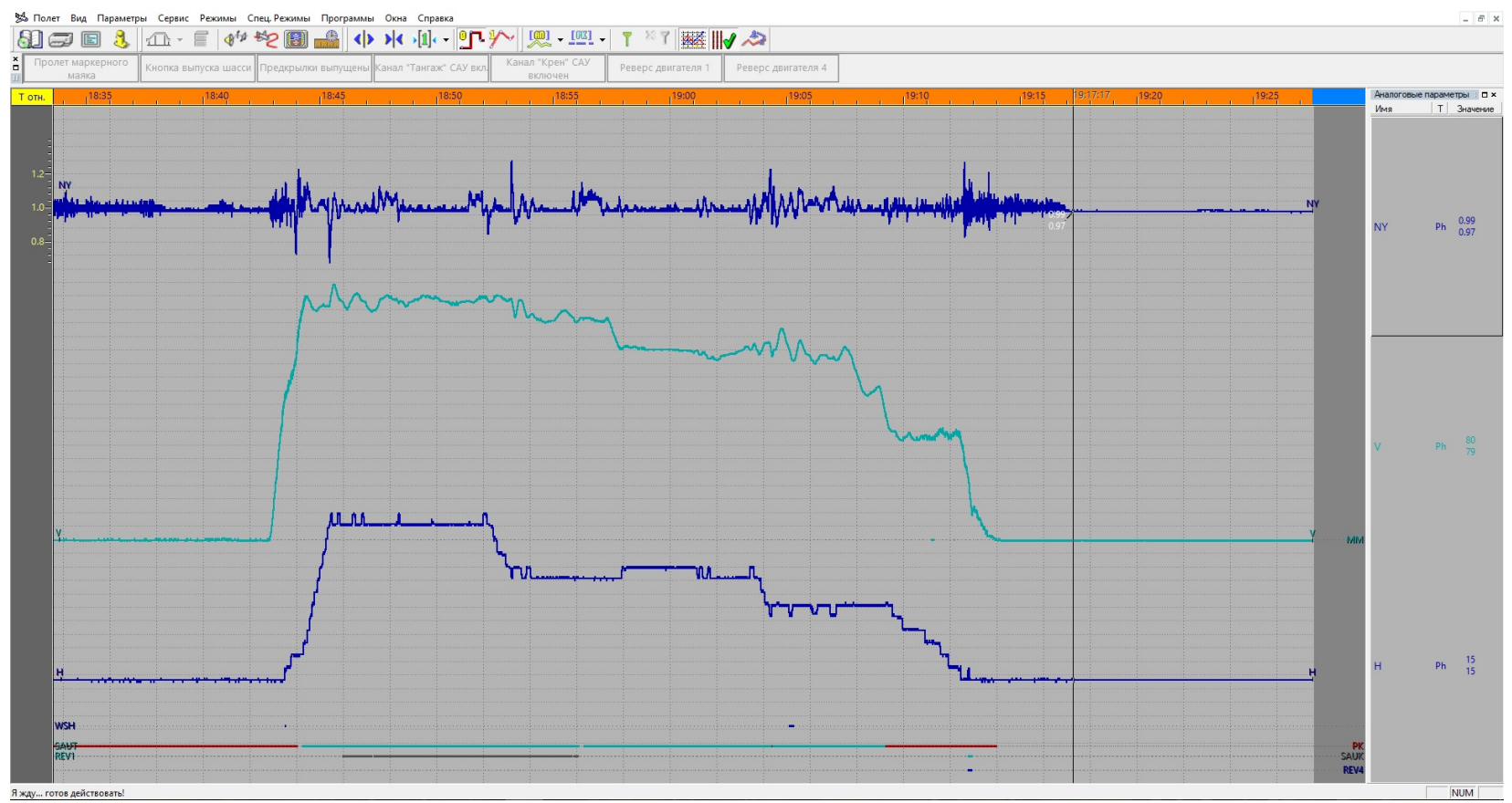

Рис. 1. Сигналограма польоту літака Ил-76МД № 76683(0063468029).

Джерело: розроблено авторами.

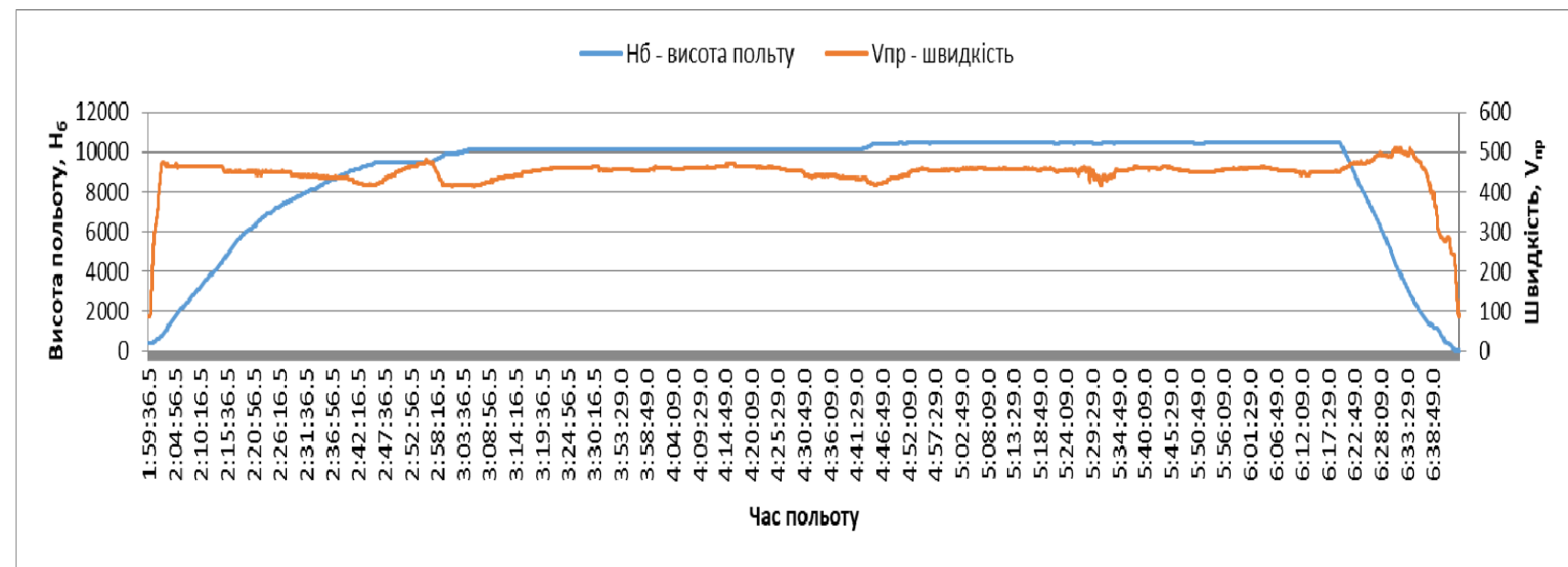

—лу - Іеревангаження у цен пі мас

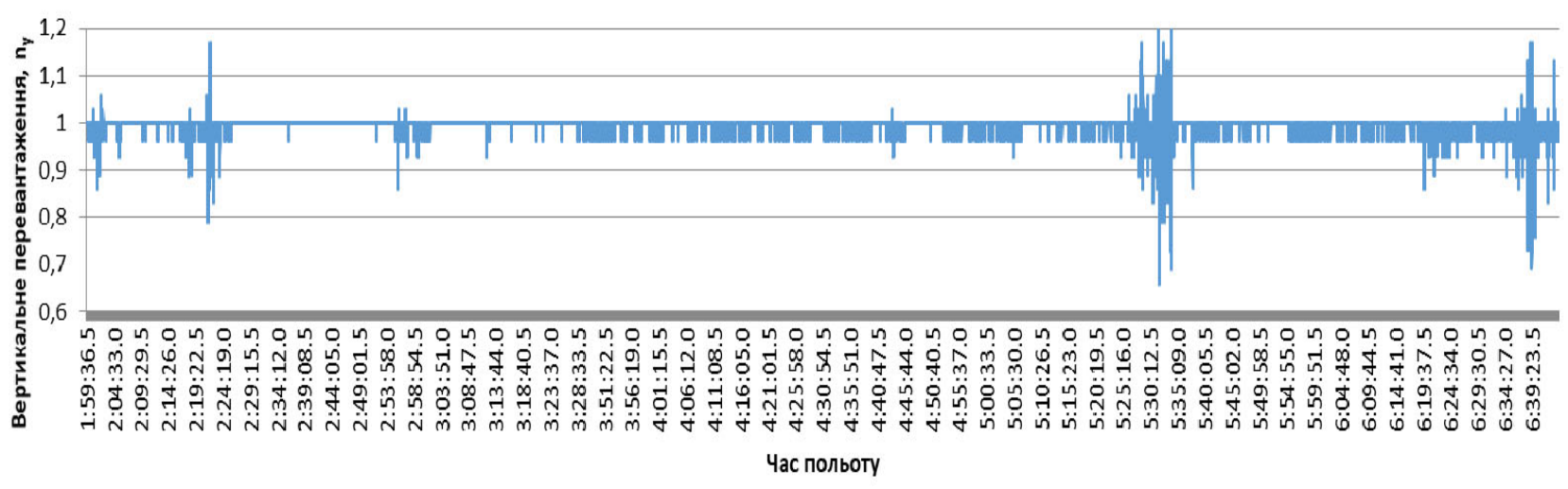

Рис. 2. Висота польоту $-H_{\sigma}$, приладова швидкість $-V_{n p}$ та вертикальне перевантаження $-n_{y}$ у залежності від часу польоту (12-Польотні завдання Ил-76№ 683 07.08.20).

Джерело: розроблено авторами. 
Значення пікових перевантажень $\mathrm{n}_{\mathrm{y}}$ записується наступним чином: перша стрічка має значення перший мінімум перевантаження у запису $n_{y}^{\min }$, далі друга стрічка - перший максимум $n_{y}^{\max }$, третя стрічка - другий мінімум $n_{y}^{\min }$, четверта стрічка другий максимум $n_{y}^{\max }$. I таким чином весь політ.

Отриманий FILE - “12 - Польотні завдання Ил-76 № 683 07.08.20.txt” має графічний вигляд у програмі EXCEL (Рис. 2). У порівнянні з первинним графіком (Рис. 1) він значно значно спрощений і має на порядок менший об'єм займаної пам'яті. Спрощення полягає у знаходженні та відновленні екстремумів залежності перевантаження за часом шляхом вилучення проміжних (маленьких) змін навантаження, які поглинаються великими циклами перевантаження i не впливають на вичерпання технічного ресурсу силових елементів планера літака. 3 метою реалізації даного спрощення та можливості подальшого використання отриманого масиву даних фахівцями ДНДІА додатково розроблена програма для відновлення екстремумів табличного масиву даних $n_{y}(t)$.

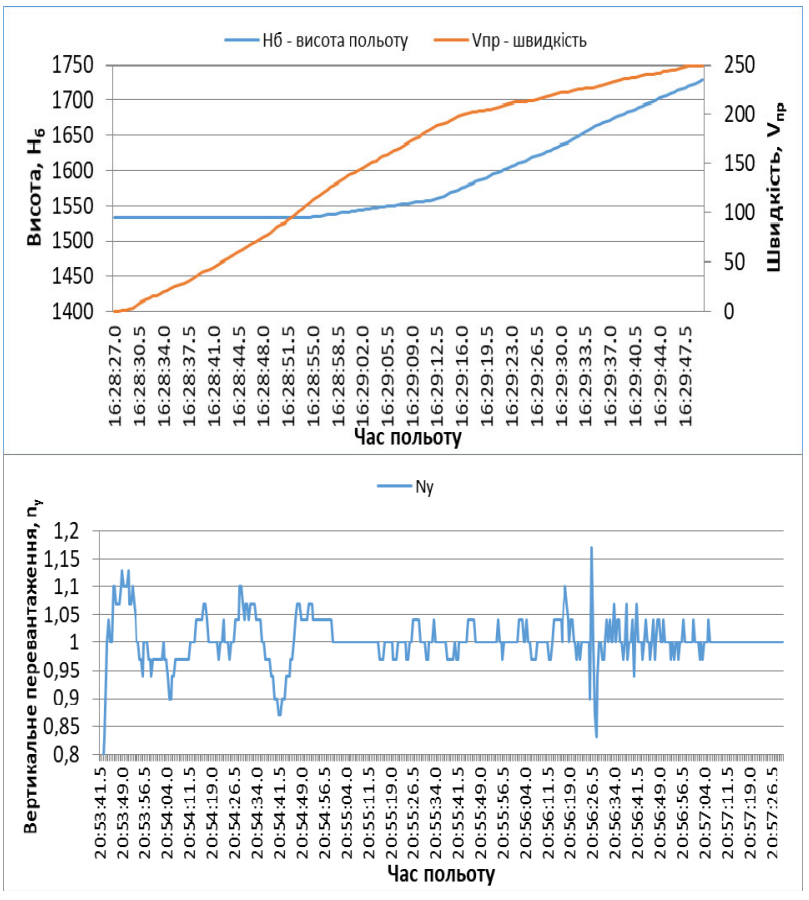

Рис. 3. Оброблені графіки висоти польоту $-H_{\sigma}$,

приладової швидкості - $V_{n p}$ та вертикального

перевантаження - $n_{y}$ у залежності від часу польоту

(Зліт 15 - Польотні завдання Ил-76№ 699 05.06.20). Джерело: розроблено авторами.

На рисунку 2 проілюстровано характерний цикл навантаження силової конструкції планера транспортного літака типу Ил-76 “ЗЕМЛЯПОВІТРЯ-ЗЕМЛЯ” (ЗПЗ). Найбільший внесок у втрату ресурсу силових елементів планера літака визначають три режими польоту, а саме: режим зльоту (Рис. 3.), режим посадки (Рис. 4.) та режим польоту у бовтанку (Рис. 5.).

Під час зльоту навантажуються силові елементи злітно-посадкових пристроїв, пов'язані зі значною злітною масою. Також при зльоті мають значне навантаження силові елементи, особливо верхньої панелі крила літака. Це навантаження пов'язано з масою палива, яке розташовано у крильових паливних баках.
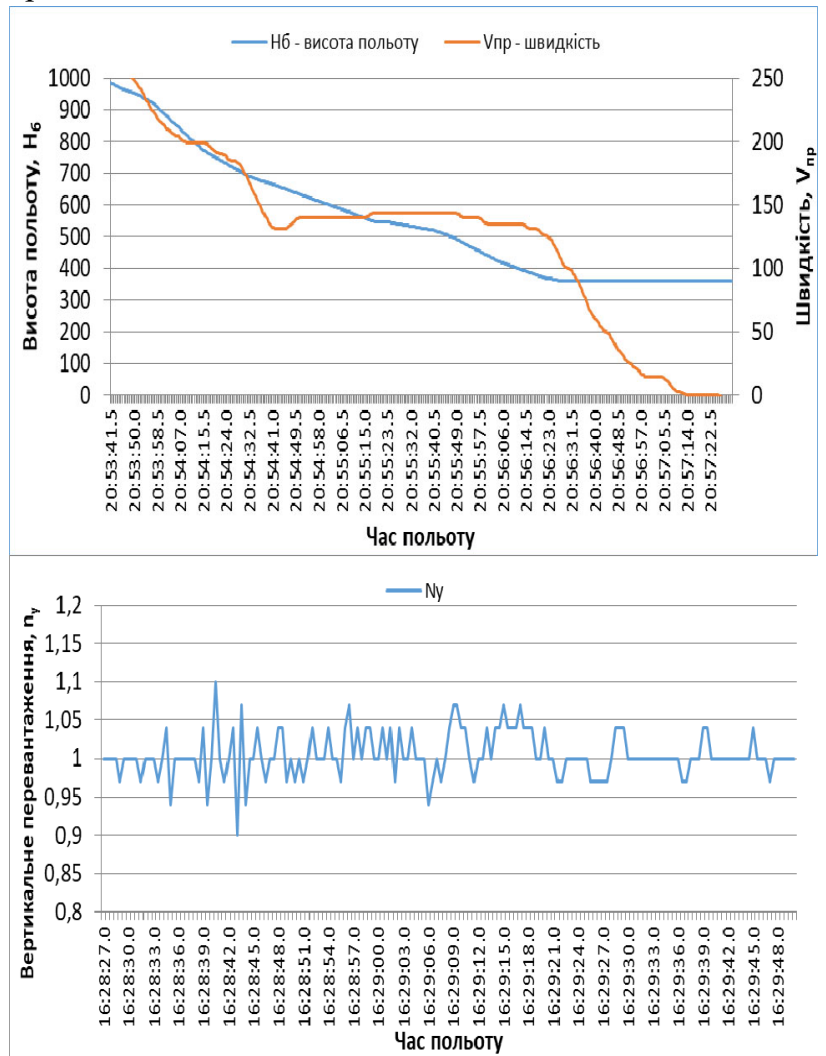

Рис. 4. Оброблені графіки висоти польоту - $H_{\sigma}$, приладової швидкості - $V_{n p}$ та вертикального перевантаження - $n_{y}$ у залежності від часу польоту (Посадка - Ил-76№ 699 05.06.20). Джерело: розроблено авторами.

Під час посадки літака виникає навантаження планера i злітно-посадкових пристроїв при поглинанні та розсіюванні кінетичної енергії, яка пов'язана 3 вертикальною i горизонтальною швидкістю та посадковою масою літака. Навантаження силових елементів крила при посадці менше, ніж при зльоті, у зв'язку зі зменшенням маси палива, що було розміщено у крильових баках.

На рисунку 3 показано випадок виникнення бовтанки літака Ил-76 № 68307 серпня 2020 року протягом 11 хвилин з 5:24 до 5:35 на висоті близько 10500 метрів. Ймовірно виникнення бовтанки на такій висоті пов'язано з польотом над високогірним масивом. 

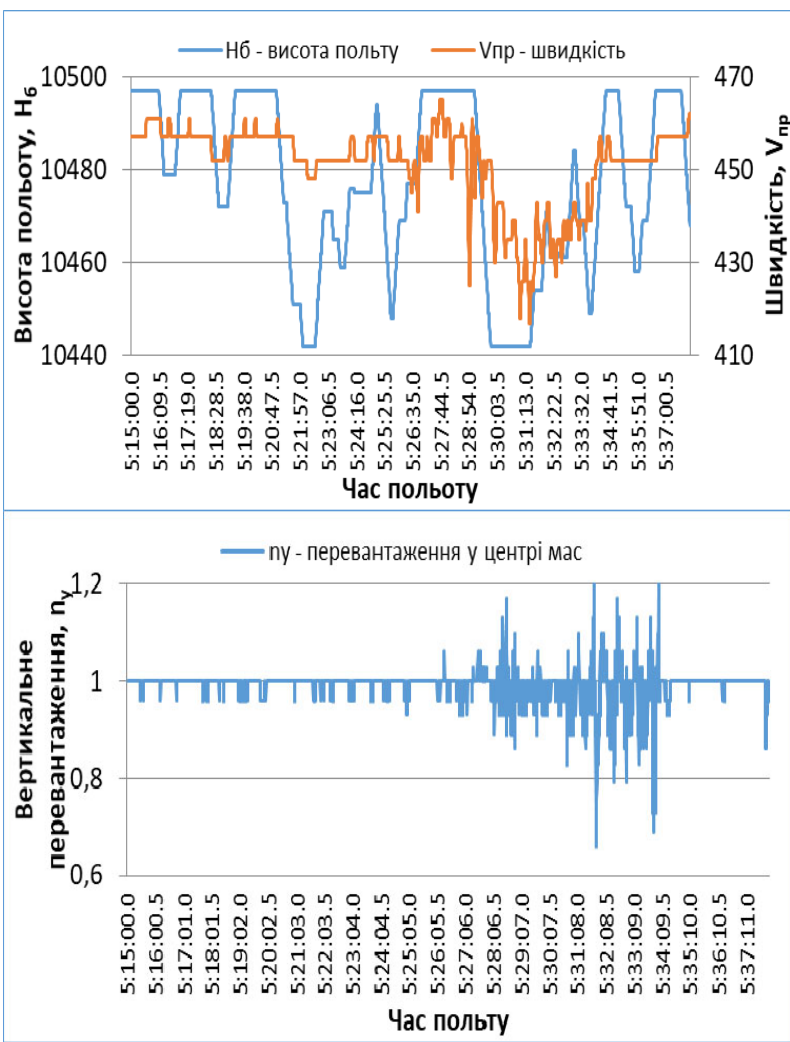

Рис. 5. Оброблені графіки висоти польоту $-H_{\sigma}$, приладової швидкості $V_{n p}$ та вертикального

перевантаження - $n_{y}$ у залежності від часу польоту

(Бовтанка - Ил-76№ 683 07.08.20).

Джерело: розроблено авторами.

Цей випадок виникнення бовтанки більш ретельно проілюстровано на рисунку 5. Перепад $\Delta H_{\sigma}$ - барометричної висоти складав приблизно 60 метрів при зміні $\Delta V_{n p}-$ приладової швидкості близько 50 км/год. Під час цієї бовтанки спостерігається значні коливання конструкції літака $\mathrm{i}$, як наслідок, флуктація $n_{y}$ - перевантаження у центрі мас літака. Подібні випадки бовтанки приводять до суттєвої витрати ресурсу силових елементів планера літака та безпосередньо силових елементів крила.

Таким чином, сформовано масив даних (таблиця 2) та відповідно для кожного 3 20-ти польотних завдань оброблено файл даних у вигляді масиву значень перевантаження за часом для подальшого розрахунку витати ресурсу силових елементів літака типу Ил-76 3 використанням гіпотези лінійного підсумування втомленісних пошкоджень. Прийнятий у роботі метод розрахунку вичерпання ресурсу містить у собі перевірену багаторічною практикою методику розрахунку ресурсу $[1 \ldots 3 ; 6$, с. 224$]$, засновану на лінійній гіпотезі підсумовування втомнісних пошкоджень, а саме:

використанні наявних характеристик втомної міцності конструкції (це може бути крива втомної міцності матеріалу конструкції 3 визначеним коефіцієнтом концентрації напружень або реальна крива втомної міцності цієї конструкції, одержана експериментальним шляхом);

аналізі поточної (з використанням даних бортових записів параметрів польоту) або статистичної інформації при повторенні навантаження, що діють на конструкцію або іiі елементи протягом життєвого циклу.

Бортові засоби контролю параметрів польоту несуть інформацію, якої достатньо для розрахунків реальної повторюваності навантажень у польоті.

Bci навантаження, записані бортовими самописцями, систематизуються певним порядком. Найбільше поширення має метод систематизації навантажень, який одержав найменування "метод повних циклів".

За підготовленими даними таблиць у відповідних файлах формату *.txt фахівцями ДНДІА проводяться розрахунки із застосуванням спеціальної програми на ЕОМ - розраховуються еквіваленти нальоту - $\left(E K V_{i}\right)$, коефіцієнти витрати ресурсів $\left(K R R_{i}\right)$, величина сумарного за політ питомого пошкодження від втоми у силових елементах крила для кожного польотного завдання.

$E K V_{i}$ розраховується безпосередньо у годинах нальоту, а $K R R_{i}-$ у порівнянні 3 типовим польотним завданням, за яким розробник призначив ресурсні показники (для літака Ил-76 ресурс за типовим польотним завданням складає 5000 годин).

Сумарне за політ питоме пошкодження від втоми $\xi_{\Sigma}$ (у програмному інтерфейсі - Ksi) розраховується як доля від 0 до 1 .

Рівень $\xi_{\Sigma}=1 \quad \epsilon$ максимально допустимою величиною пошкодження від втоми i означає граничний стан - повну витрату ресурсних можливостей літака згідно з прийнятою гіпотезою лінійного підсумовування пошкоджень. Слід зауважити, що згідно з діючими нормами міцності в алгоритм програми закладене нормоване значення запасу міцності -5 . 
Таблиця 2

Відомості про виконання польотного завдання літаків Ил-76

\begin{tabular}{|l|l|c|c|c|c|c|}
\hline FILE & $\begin{array}{c}\text { Номер літака / дата } \\
\text { польоту }\end{array}$ & $\begin{array}{c}\text { Маса } \\
\text { злітна, } \\
\text { кг }\end{array}$ & $\begin{array}{c}\text { Маса } \\
\text { посадкова, кг }\end{array}$ & $\begin{array}{c}\text { Витрата } \\
\text { палива, кг }\end{array}$ & $\begin{array}{c}\text { Час } \\
\text { польоту }\end{array}$ & $\begin{array}{c}\text { Максимальне } \\
\text { перевантаження } n_{y}\end{array}$ \\
\hline 1. & № $683 / 06.08 .20$ & 159000 & 132000 & 27000 & $3-48$ & 1,21 \\
\hline 2. & № $683 / 21.01 .21$ & 181000 & 143000 & 38000 & $4-44$ & 1,42 \\
\hline 3. & № $699 / 08.12 .20$ & 172000 & 114000 & 58000 & $7-04$ & 1,2 \\
\hline 4. & № $413 / 07.02 .20$ & 181000 & 140000 & 41000 & $5-06$ & 1,5 \\
\hline 5. & № $699 / 20.04 .20$ & 188000 & 125000 & 63000 & $7-52$ & 1,39 \\
\hline 6. & № $683 / 07.08 .20$ & 169000 & 129000 & 40000 & $5-00$ & 1,17 \\
\hline 7. & № $683 / 07.08 .20$ & 169000 & 129000 & 40000 & $4-58$ & 1,17 \\
\hline 8. & № $820 / 19.08 .20$ & 172000 & 133000 & 39000 & $5-34$ & 1,29 \\
\hline 9. & № $683 / 22.06 .20$ & 180000 & 129000 & 51000 & $6-49$ & 1,62 \\
\hline 10. & № $699 / 30.06 .20$ & 162000 & 115000 & 47000 & $6-40$ & 1,23 \\
\hline 11. & № $413 / 08.02 .20$ & 140000 & 114000 & 26000 & $4-47$ & 1,33 \\
\hline 12. & № $820 / 25.05 .20$ & 171000 & 123000 & 48000 & $6-28$ & 1,35 \\
\hline 13. & № 697/13.04.20 & 166000 & 126000 & 40000 & $5-42$ & 1,19 \\
\hline 14. & № $820 / 11.12 .20$ & 170000 & 135000 & 35000 & $5-07$ & 1,16 \\
\hline 15. & № 699/05.06.20 & 160000 & 125000 & 35000 & $4-49$ & 1,36 \\
\hline 16. & № 697/10.11.20 & 136000 & 126000 & 10000 & $1-39$ & $2,6(1,26)$ \\
\hline 17. & № $820 / 28.07 .20$ & 179000 & 149000 & 30000 & $3-35$ & 1,32 \\
\hline 18. & № 732/26.11.20 & 141000 & 120000 & 21000 & $2-57$ & 1,34 \\
\hline 19. & № $413 / 17.02 .21$ & 140000 & 120000 & 20000 & $2-56$ & 1,42 \\
\hline 20. & № $820 / 22.05 .20$ & 166000 & 122000 & 44000 & $6-25$ & 1,19 \\
\hline
\end{tabular}

Джерело: розроблено авторами

Інтерфейс програми наведено на рисунках 6, 7. Розрахункова програма потребує введення заздалегідь підготовлених вхідних даних щодо відповідного польотного завдання. Також необхідно ввести напруження горизонтального польоту, що діє у панелі крила, термін призначеного ресурсу для літака та термін даного польоту.

Крім того, проводяться прямі розрахунки фактичної витрати ресурсу для польотних завдань, для яких проводилась детальна обробка.

$$
T_{\phi}=\sum_{i=1}^{n} E K V_{i} .
$$

Порівняння цієї величини 3 фактичним нальотом (перебуванням літака у повітрі), розрахованим за формулярними даними, дає відповідь на питання: чи є залишок ресурсу, для проведення збільшення показника, або його нема і якими шляхами й на скільки це збільшення можливо здійснити?

За закономірностями теорії ймовірності результат можна розповсюдити на весь парк літаків цього типу.

3 використанням середніх значень $K R R$ i $E K V$ можна вирішувати і питання щодо можливості індивідуального продовження ресурсних показників окремим літакам, якщо відома передісторія їх навантаження.

Хоча всі літаки проєктуються за принципом рівноміцності, i, здавалось би, всі елементи їх конструкції повинні мати однакові ресурси, насправді цього не відбувається з різних причин, тому майже на кожному типі літаків в експлуатації виявляються так звані “слабкі місця”, що створюють певні проблеми для безпеки польотів i, відповідно, для продовження i збільшення призначених показників. 
Конкретний політ літака тривалістю $T$ за сукупністю діючих повторних навантажень може значною мірою відрізняться від “еталонного” польоту, що покладений виробником в основу розрахунку призначеного ресурсу літака $T_{n}$. Коефіцієнт витрати ресурсу в даному типі польотного завдання розраховується за формулою:

$$
K R R_{i}=T / T_{n}
$$

У загальному випадку величина $K R R_{i}$ може дорівнювати одиниці, бути більшою, або меншою за одиницю в залежності від інтенсивності навантаження літака в даному типі польотних завдань. Тож вести облік витрати ресурсу без урахування цього коефіцієнта, тобто без урахування ступеня навантаженості його конструкції в польоті, некоректно. Еквівалент витрати ресурсу дорівнює:

$$
E K V_{i}=K R R_{i} \cdot t_{n}
$$

де $t_{n}$ - час, витрачений на виконання польотного завдання. Саме ця величина визначає долю накопиченого пошкодження від втоми в даному польотному завданні і саме за нею слід вести облік витрати ресурсу літака.

Втілення системи обліку витрати ресурсу за еквівалентом $E K V_{i}$ - це один із шляхів для збільшення призначених ресурсів і переведення літаків на експлуатацію за технічним станом за ресурсними показниками.

Розрахунки проводились у ДНДІА 3 застосуванням спеціальної програми на ЕОМ [4, с. 109]. На рисунках 6, 7 наведено приклад розрахунків за даними записів засобів об'єктивного контролю. Отримані результати розрахунків еквіваленту нальоту $E K V_{i}$, коефіцієнту витрати ресурсів $K R R_{i}$ та значення втомного пошкодження силових елементів для кожного польотного завдання, наведеного у таблиці 2.

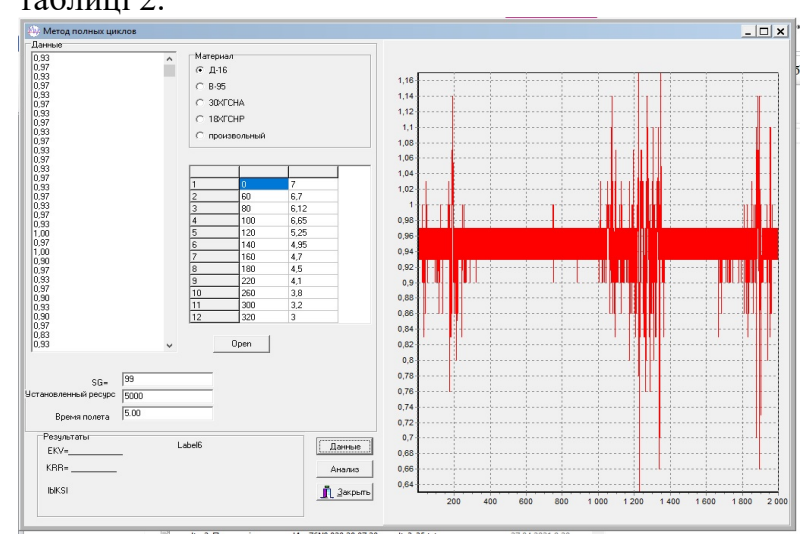

Рис. 6. Інтерфейс розрахункової програми після введення даних.

Джерело: розроблено авторами.

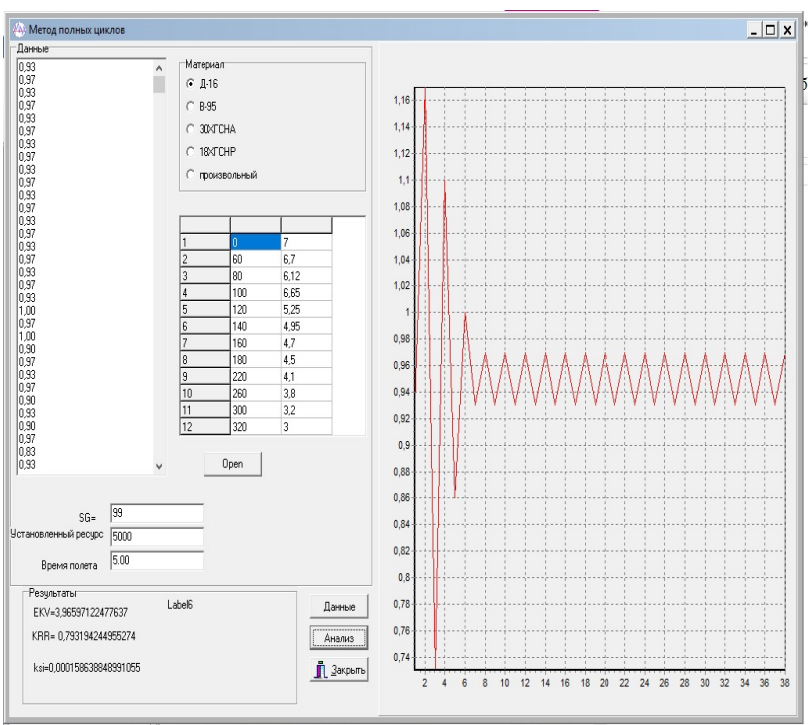

Рис. 7. Інтерфейс проведення аналізу. Джерело: розроблено авторами.

Результат додатково виводиться в файлі FILE=result (назва файлу, що містить вихідні дані).txt у такій формі:

FILE=Ил-76№ 683 07.08.20_5-00.txt

$\mathrm{SG}=99$

Встановлений ресурс, год. $=5000$

Час польоту, хв. $=300$

$E K V=3,96597122477637$

$K R R=0,793194244955274$

$K s i=0,000158638848991055$.

Далі по кожному 3 польотних завдань окремо проводиться стандартна статистична обробка - визначаються значення $K R R$ i ïx квадратичне відхилення, необхідні для виконання подальших ймовірнісних розрахунків 3 метою обгрунтування прийняття рішення про можливість (неможливість) збільшення ресурсних показників.

Загальні результати розрахунків еквівалентів нальоту $(E K V)$, коефіцієнтів витрати ресурсу $(K R R)$ та втомного пошкодження силових елементів крила літака Ил-76 $(K s i)$ для 20-ти польотних завдань наведені в таблиці 3.

Отримані розрахункові дані доцільно узагальнити та звести до підсумкової таблиці 4 для подальшого аналізу. 
Результати розрахунків еквіваленту нальоту, коефіцієнту витрати ресурсу та втомного пошкодження

\begin{tabular}{|c|c|c|c|c|}
\hline $\begin{array}{l}\text { Ил-76№ } 413 \text { 07.02.20_5-06.txt } \\
\text { SG=99 } \\
\text { Встановлений ресурс, год. }=5000 \\
\text { Час польоту хв. =306 } \\
\text { EKV=3,41689372249051 } \\
\text { KRR=0,669979161272649 } \\
\text { ksi=0,00013667574889962 }\end{array}$ & 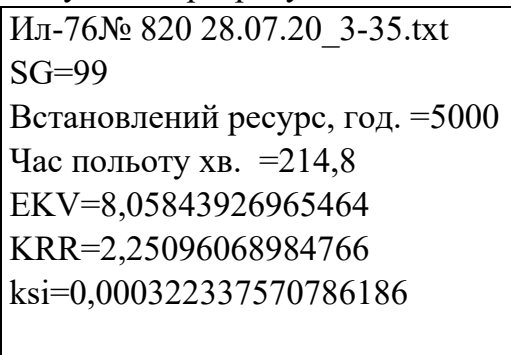 & $\begin{array}{l}\text { Ил-76№ } 82011.12 .20 \_5-07-2 . t x t \\
\mathrm{SG}=99 \\
\text { Встановлений ресурс, год. }=5000 \\
\text { Час польоту хв. }=307,2 \\
\mathrm{EKV}=5,87494594914065 \\
\mathrm{KRR}=1,14745038069153 \\
\mathrm{ksi}=0,000234997837965626\end{array}$ & $\begin{array}{l}\mathrm{SG}=99 \\
\text { Встановлений ресурс, год. } \\
=5000 \\
\text { Час польоту хв. }=409,2 \\
\mathrm{EKV}=6,27567623931996 \\
\mathrm{KRR}=0,920187131865097 \\
\mathrm{ksi}=0,000251027049572799\end{array}$ & $\begin{array}{l}\text { Ил-76№ } 697 \text { 13.04.20_5-42.txt } \\
\mathrm{SG}=99 \\
\text { Встановлений ресурс, год. } \\
=5000 \\
\text { Час польоту хв. }=342 \\
\mathrm{EKV}=6,35116346332427 \\
\mathrm{KRR}=1,11423920409198 \\
\mathrm{ksi}=0,000254046538532971\end{array}$ \\
\hline 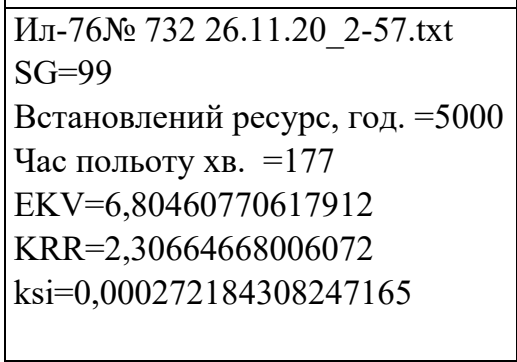 & $\begin{array}{l}\text { Ил-76№ } 699 \text { 8.12.20_7-04.txt } \\
\mathrm{SG}=99 \\
\text { Встановлений ресурс, год. }=500( \\
\text { Час польоту хв. }=424,2 \\
\mathrm{EKV=4,37672386099232} \\
\mathrm{KRR}=0,619055708768362 \\
\mathrm{ksi}=0,000175068954439693\end{array}$ & $\begin{array}{l}\text { Ил-76№ } 697 \text { 10.11.20_1-39.txt } \\
\mathrm{SG}=99 \\
\text { Встановлений ресурс, год. }=500( \\
\text { Час польоту хв. }=99 \\
\mathrm{EKV=3,31724329525462} \\
\mathrm{KRR}=2,01045048197249 \\
\mathrm{ksi}=0,000132689731810185\end{array}$ & $\begin{array}{l}\text { Ил-76№ } 699 \text { 20.04.20_7-52.txt } \\
\mathrm{SG}=99 \\
\text { Встановлений ресурс, год. } \\
=5000 \\
\text { Час польоту хв. }=472,2 \\
\mathrm{EKV}=5,96712736439586 \\
\mathrm{KRR}=0,758211863328571 \\
\mathrm{ksi}=0,000238685094575834\end{array}$ & $\begin{array}{l}\text { Ил-76№ } 699 \text { 30.06.20_6-40.txt } \\
\mathrm{SG}=99 \\
\text { Встановлений ресурс, год. } \\
=5000 \\
\text { Час польоту хв. }=384 \\
\text { EKV=6,09415820925275 } \\
\mathrm{KRR}=0,952212220195743 \\
\mathrm{ksi}=0,00024376632837011\end{array}$ \\
\hline $\begin{array}{l}\text { Ил-76№ } 683 \text { 21.01.21_4-44.txt } \\
\text { SG=99 } \\
\text { Встановлений ресурс, год. }=5000 \\
\text { Час польоту хв. =283,8 } \\
\text { EKV=2,87540394545769 } \\
\text { KRR=0,607907810879005 } \\
\text { ssi=0,000115016157818308 }\end{array}$ & 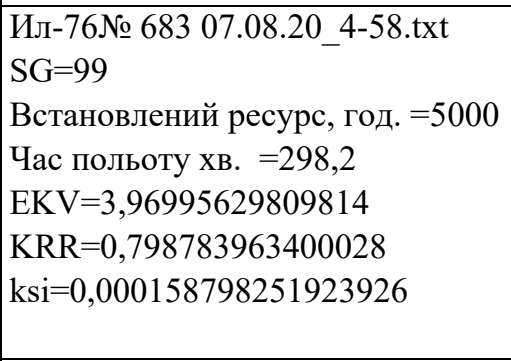 & $\begin{array}{l}\text { Ил-76№ } 683 \text { 06.08.20_3-48.txt } \\
\mathrm{SG}=99 \\
\text { Встановлений ресурс, год. }=5000 \\
\text { Час польоту хв. }=228 \\
\mathrm{EKV}=1,18195272658736 \\
\mathrm{KRR}=0,311040191207201 \\
\mathrm{ksi}=4,72781090634945 \mathrm{E}-5\end{array}$ & $\begin{array}{l}\text { Ил-76№ } 820 \text { 22.05.20_6-25.txt } \\
\mathrm{SG}=99 \\
\text { Встановлений ресурс, год. } \\
=5000 \\
\text { Час польоту хв. }=385,2 \\
\mathrm{EKV}=20,5886282388354 \\
\mathrm{KRR}=3,20695143907093 \\
\mathrm{ksi}=0,000823545129553415\end{array}$ & $\begin{array}{l}\text { Ил-76№ } 82025.05 .20 \_6-28 . t x t \\
\mathrm{SG}=99 \\
\text { Встановлений ресурс, год. } \\
=5000 \\
\text { Час польоту хв. }=388,2 \\
\mathrm{EKV}=6,95344056230259 \\
\mathrm{KRR}=1,07472033420442 \\
\mathrm{ksi}=0,000278137622492103\end{array}$ \\
\hline $\begin{array}{l}\text { Ил-76№ } 413 \text { 17.02.21_2-56.txt } \\
\text { SG=99 } \\
\text { Встановлений ресурс, год. }=5000 \\
\text { Час польоту хв. }=175,8 \\
\text { EKV=7,62755552979434 } \\
\text { KRR=2,60326127296735 } \\
\text { ksi=0,000305102221191774 }\end{array}$ & $\begin{array}{l}\text { Ил-76№ } 413 \text { 08.02.20_4-47.txt } \\
\mathrm{SG}=99 \\
\text { Встановлений ресурс, год. }=5000 \\
\text { Час польоту хв. }=286,8 \\
\mathrm{EKV}=4,75114302703577 \\
\mathrm{KRR}=0,993962976367316 \\
\mathrm{ksi}=0,000190045721081431\end{array}$ & $\begin{array}{l}\text { Ил-76№ } 683 \text { 07.08.20_5-00.txt } \\
\mathrm{SG}=99 \\
\text { Встановлений ресурс, год. }=5000 \\
\text { Час польоту хв. }=300 \\
\mathrm{EKV}=3,96597122477637 \\
\mathrm{KRR}=0,793194244955274 \\
\mathrm{ksi}=0,000158638848991055\end{array}$ & $\begin{array}{l}\text { Ил-76№ } 699 \text { 05.06.20_4-49.txt } \\
\mathrm{SG}=99 \\
\text { Встановлений ресурс, год. } \\
=5000 \\
\text { Час польоту хв. }=289,2 \\
\mathrm{EKV}=6,18204815167193 \\
\mathrm{KRR}=1,28258260408131 \\
\mathrm{ksi}=0,000247281926066877\end{array}$ & $\begin{array}{l}\text { Ил-76№ } 82019.08 .20 \_5-34 . t x t \\
\mathrm{SG}=99 \\
\text { Встановлений ресурс, год. } \\
=5000 \\
\text { Час польоту хв. }=334,2 \\
\mathrm{EKV}=4,91122019925332 \\
\mathrm{KRR}=0,881727145287848 \\
\mathrm{ksi}=0,000196448807970133\end{array}$ \\
\hline
\end{tabular}


Таблиця 4

Узагальнені результати розрахунків

\begin{tabular}{|c|c|c|c|c|c|c|c|c|c|}
\hline \\
\hline FILE & $\begin{array}{l}\text { Номер літака / } \\
\text { дата польоту }\end{array}$ & $\begin{array}{c}\text { Маса } \\
\text { злітна, } \\
\text { кг }\end{array}$ & $\begin{array}{c}\text { Маса } \\
\text { посадкова, } \\
\text { кг }\end{array}$ & $\begin{array}{c}\text { Витрата } \\
\text { палива, } \\
\text { кг }\end{array}$ & $\begin{array}{c}\text { Час } \\
\text { польоту }\end{array}$ & $\begin{array}{c}\text { Максимальне } \\
\text { перевантаження } \\
n_{y}\end{array}$ & $\begin{array}{l}\text { Еквівалентний час } \\
\text { польоту - } E K V\end{array}$ & $\begin{array}{c}\text { Коефіцієнт витрати } \\
\text { ресурсу - KRR }\end{array}$ & $\begin{array}{c}\text { Втомне пошкодження - } \\
K s i\end{array}$ \\
\hline 1. & № 683 /06.08.20 & 159000 & 132000 & 27000 & $3: 48$ & 1,21 & 1,18195272658736 & 0,311040191207201 & 0,000047278109063495 \\
\hline 2. & № $683 / 21.01 .21$ & 181000 & 143000 & 38000 & $4: 44$ & 1,42 & 2,87540394545769 & 0,607907810879005 & 0,000115016157818308 \\
\hline 3. & № $699 / 08.12 .20$ & 172000 & 114000 & 58000 & $7: 04$ & 1,2 & 4,37672386099232 & 0,619055708768362 & 0,000175068954439693 \\
\hline 4. & № 413/ 07.02.20 & 181000 & 140000 & 41000 & $5: 06$ & 1,5 & 3,41689372249051 & 0,669979161272649 & 0,00013667574889962 \\
\hline 5. & № $699 / 20.04 .20$ & 188000 & 125000 & 63000 & $7: 52$ & 1,39 & 5,96712736439586 & 0,758211863328571 & 0,000238685094575834 \\
\hline 6. & № 683 /07.08.20 & 169000 & 129000 & 40000 & $5: 00$ & 1,17 & 3,96597122477637 & 0,793194244955274 & 0,000158638848991055 \\
\hline 7. & № 683 /07.08.20 & 169000 & 129000 & 40000 & $4: 58$ & 1,17 & 3,96995629809814 & 0,798783963400028 & 0,000158798251923926 \\
\hline 8. & № $820 / 19.08 .20$ & 172000 & 133000 & 39000 & $5: 34$ & 1,29 & 4,91122019925332 & 0,881727145287848 & 0,000196448807970133 \\
\hline 9. & № $683 / 22.06 .20$ & 180000 & 129000 & 51000 & $6: 49$ & 1,62 & 6,27567623931996 & 0,920187131865097 & 0,000251027049572799 \\
\hline 10. & № $699 / 30.06 .20$ & 162000 & 115000 & 47000 & $6: 40$ & 1,23 & 6,09415820925275 & 0,952212220195743 & 0,00024376632837011 \\
\hline 11. & № 413 /08.02.20 & 140000 & 114000 & 26000 & $4: 47$ & 1,33 & 4,75114302703577 & 0,993962976367316 & 0,000190045721081431 \\
\hline 12. & № $820 / 25.05 .20$ & 171000 & 123000 & 48000 & $6: 28$ & 1,35 & 6,95344056230259 & 1,07472033420442 & 0,000278137622492103 \\
\hline 13. & № $697 / 13.04 .20$ & 166000 & 126000 & 40000 & $5: 42$ & 1,19 & 6,35116346332427 & 1,11423920409198 & 0,000254046538532971 \\
\hline 14. & № $820 / 11.12 .20$ & 170000 & 135000 & 35000 & $5: 07$ & 1,16 & 6,23871918514172 & 1,21849984084799 & 0,000249548767405669 \\
\hline 15. & № $699 / 05.06 .20$ & 160000 & 125000 & 35000 & $4: 49$ & 1,36 & 6,18204815167193 & 1,28258260408131 & 0,000247281926066877 \\
\hline 16. & № $697 / 10.11 .20$ & 136000 & 126000 & 10000 & $1: 39$ & 1,26 & 3,31724329525462 & 2,01045048197249 & 0,000132689731810185 \\
\hline 17. & № $820 / 28.07 .20$ & 179000 & 149000 & 30000 & $3: 35$ & 1,32 & 8,05843926965464 & 2,25096068984766 & 0,000322337570786186 \\
\hline 18. & № $732 / 26.11 .20$ & 141000 & 120000 & 21000 & $2: 57$ & 1,34 & 6,80460770617912 & 2,30664668006072 & 0,000272184308247165 \\
\hline 19. & № $413 / 17.02 .21$ & 140000 & 120000 & 20000 & $2: 56$ & 1,42 & 7,62755552979434 & 2,60326127296735 & 0,000305102221191774 \\
\hline 20. & № $820 / 22.05 .20$ & 166000 & 122000 & 44000 & $6: 25$ & 1,19 & 20,5886282388354 & 3,20695143907093 & 0,000823545129553415 \\
\hline & & агалом: & & & $102: 00$ & & $127: 01$ & & \\
\hline
\end{tabular}

Джерело: розроблено авторами.

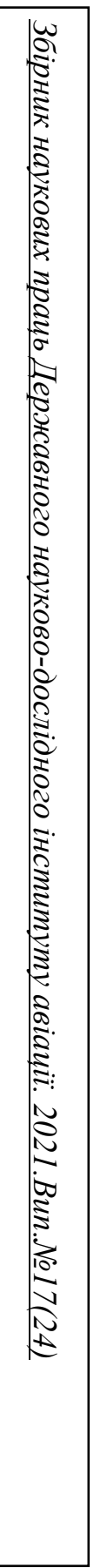


За результатами наведених у таблиці розрахунків витрата ресурсу, відповідно за коефіцієнтом витрати ресурсу $K R R$, як міри накопичення втомних пошкоджень, для польотних завдань склала 127 годин при нальоті (час перебування літаків у польоті) 102 години.

Еквівалентна витрата ресурсу у деяких польотах значно більша фактичного нальоту. Це пов'язане зі значними значеннями максимального вертикального перевантаження під час виконання даних польотних завдань. Для літака Ил-76 максимальне експлуатаційне вертикальне перевантаження, що встановлено розробником, дорівнює $n_{y \max }^{e}=2,5$. Дана вибірка польотних завдань має 9 польотів 3 максимальним експлуатаційним вертикальне перевантаженням $n_{y \max }^{e}>1,3$.

Розрахунки довели, що графічна залежність коефіцієнта витрати ресурсу $K R R$ і втомнісного пошкодження від максимального перевантаження має лінійну апроксимацію (рисунки 8, 9) та практично постійну статичну апроксимацію (Рис. 10). Також доцільно проаналізувати залежність втомнісного пошкодження i коефіцієнта витрати ресурсу $K R R$ від злітної маси під час польоту Ил-76 при виконанні певного польотного завдання (рисунки 11,12 ).

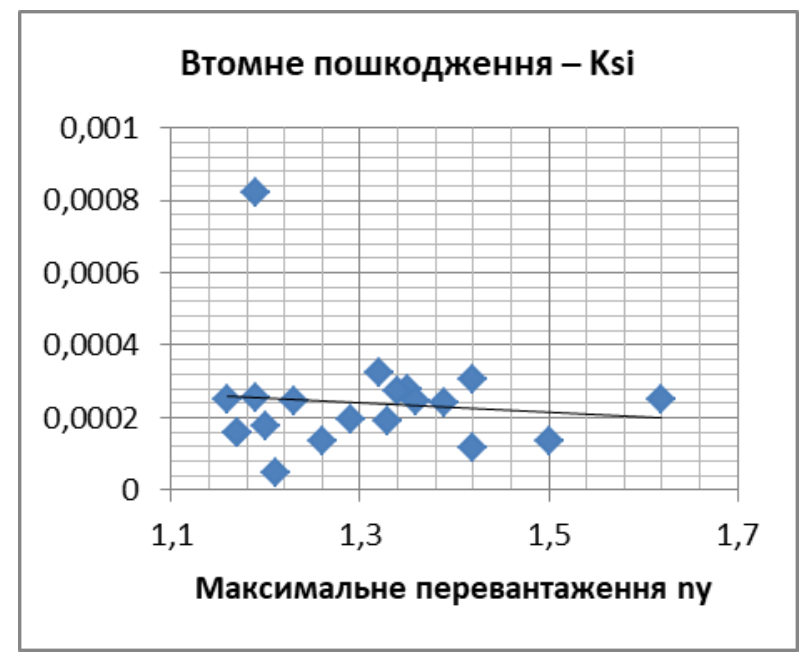

Рис. 8. Залежність втомнісного пошкодження силових елементів крила літака Ил-76 від максимального вертикального перевантаження літака.

Джерело: розроблено авторами.

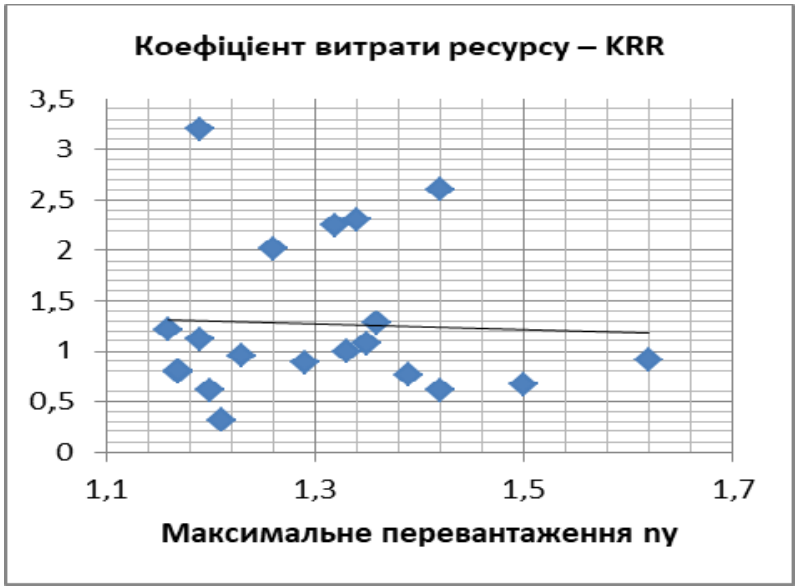

Рис. 9. Залежність коефіцієнта витрати ресурсу $K R R$ силових елементів крила літака Ил-76 від максимального вертикального перевантаження. Джерело: розроблено авторами.

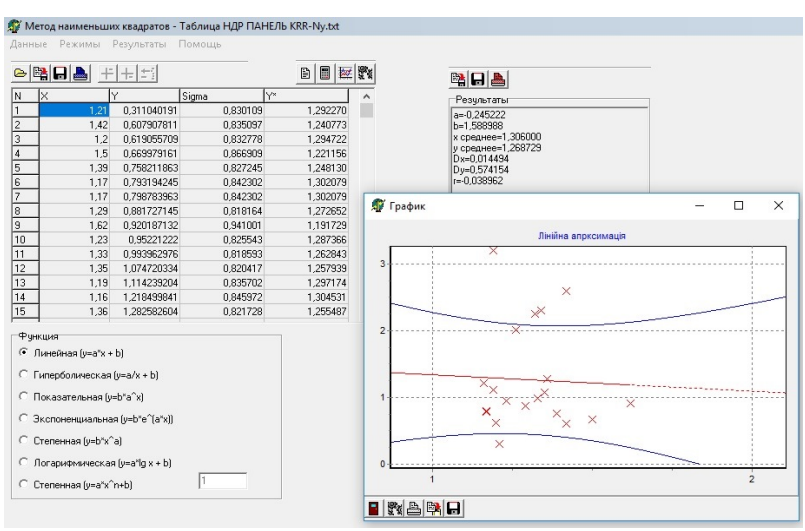

Рис. 10. Лінійна апроксимація залежності коефіцієнта витрати ресурсу $K R R$ силових елементів крила літака Ил-76 від максимального вертикального перевантаження.

Джерело: розроблено авторами.

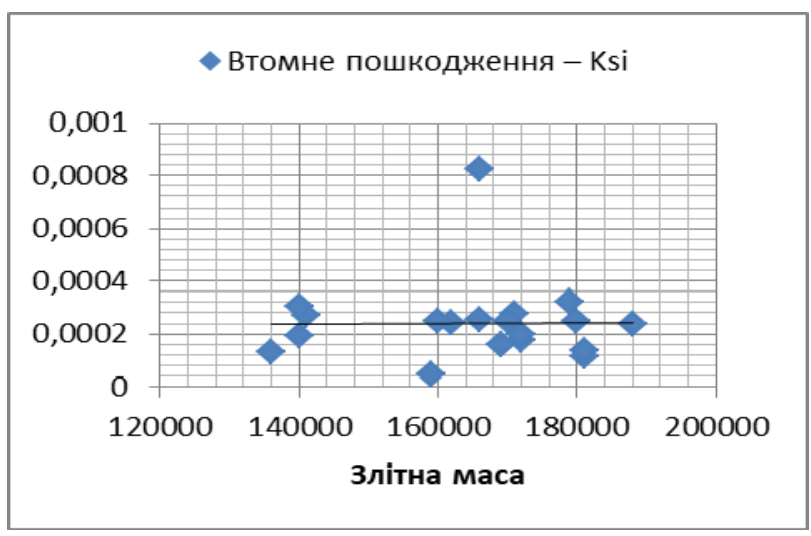

Рис. 11. Залежність втомнісного пошкодження силових елементів крила літака від злітної маси літака Ил-76.

Джерело: розроблено авторами. 


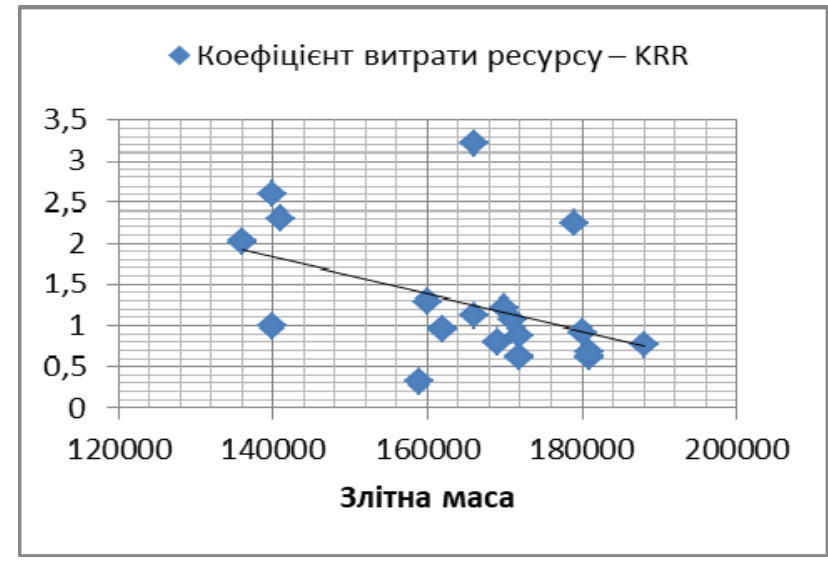

Рис. .12. Залежність коефіцієнта витрати ресурсу $K R R$ силових елементів крила від злітної маси літака Ил-76.

Джерело: розроблено авторами.
Статистичний аналіз отриманих результатів (таблиця 5) свідчить про наявність значного розкиду коефіцієнту витрати ресурсу у вибраних польотних завдань. 3 метою пошуку збільшеної кореляції наявних параметрів, проаналізуємо усі польотні завдання шляхом їх сортування за рівнем коефіцієнта витрати ресурсу $K R R$ (таблиця 4).

Після сортування за значенням коефіцієнта витрати ресурсу $K R R$ спостерігається розподіл зазначених польотних завдань на дві частини за рівнем маневрування літака. Лінія розподілу цих частин проходить на межі, де коефіцієнт витрати pecypcy $K R R$ дорівнює дві одиниці. Ця лінія розподілу також підтверджує начну зміну коефіцієнту витрати ресурсу (Рис. 8,9 ).

Таблиця 5

Результати статистичного аналізу залежності втомного пошкодження і коефіцієнта витрати ресурсу KRR від максимального перевантаження

\begin{tabular}{|l|c|c|c|c|}
\hline $\begin{array}{l}\text { Статистичний } \\
\text { параметр }\end{array}$ & $\begin{array}{c}\text { Меревантимальне } \\
\text { за політ }-n_{y}\end{array}$ & $\begin{array}{c}\text { Еквівалентний } \\
\text { час польоту } \\
\text { ЕKV }\end{array}$ & $\begin{array}{c}\text { Коефімієнт } \\
\text { витрати ресурсу }- \\
\text { KRR }\end{array}$ & $\begin{array}{c}\text { Втомлене } \\
\text { пошкодження- } \\
\text { Кsi }\end{array}$ \\
\hline Середнє & 1,306 & 5,995403611 & 1,268728748 & 0,000239816 \\
\hline $\begin{array}{l}\text { Стандартна } \\
\text { помилка }\end{array}$ & 0,027619596 & 0,861538333 & 0,173835045 & $3,44615 \mathrm{E}-05$ \\
\hline Медіана & 1,305 & 6,030642787 & 0,973087598 & 0,000241226 \\
\hline $\begin{array}{l}\text { Стандартне } \\
\text { відхилення }\end{array}$ & 0,12351859 & 3,852916556 & 0,777413954 & 0,000154117 \\
\hline $\begin{array}{l}\text { Дисперсія } \\
\text { вибірки }\end{array}$ & 0,015256842 & 14,84496598 & 0,604372456 & $2,37519 \mathrm{E}-08$ \\
\hline Ексцес & 0,584951001 & 11,58934626 & 0,66146815 & 11,58934626 \\
\hline Асиметричність & 0,876146764 & 2,985581135 & 1,240651967 & 2,985581135 \\
\hline Інтервал & 0,46 & 19,40667551 & 2,895911248 & 0,000776267 \\
\hline Мінімум & 1,16 & 1,181952727 & 0,311040191 & $4,72781 \mathrm{E}-05$ \\
\hline Максимум & 1,62 & 20,58862824 & 3,206951439 & 0,000823545 \\
\hline Сума & 26,12 & 119,9080722 & 25,37457496 & 0,004796323 \\
\hline
\end{tabular}

Джерело: розроблено авторами

\section{Висновки}

Таким чином, розрахунки темпів вичерпання ресурсних показників силових елементів планера літаків Ил-76 за фактичним навантаженням силової конструкції довели про значні витрати ресурсу у 9-ти польотних завданнях. 3 метою визначення ресурсних показників силової конструкції і оцінки можливості збільшення ресурсних показників літаків Ил-76 дослідження повинні вміщувати такі питання:

дослідження характеристик втоми та тріщиностійкості основних авіаційних матеріалів, 3 яких виготовлено силовий каркас літака;

розрахунок основних параметрів витрати pecypcy ( $E K V$ та $K R R$ ) iз застосуванням гіпотези лінійного підсумування пошкоджень втоми за типами польотних завдань;

аналіз фактичного навантаження конструкції літака при виконанні польотних завдань шляхом обробки записів засобів об'єктивного контрою після кожного польоту, а саме $n_{y}$ - вертикального навантаження у центрі мас в процесі польоту літального апарата; 
створення системи обліку фактичних значень максимального вертикального навантаження конструкції літака $-n_{y \max }$ та максимального бокового навантаження конструкції літака $-n_{z \max }$ при виконанні кожного польотного завдання шляхом обробки записів засобів об'єктивного контролю кожного польоту ЛА (дивись циклограму на рисунку 1) з фіксацій цих даних у додатковому розділі формуляра літака.

у випадку значного перевищення вертикального навантаження у центрі мас $n_{y}$ в процесі польоту ЛА, під час додаткового навантаження крила шляхом перевезення великих вантажів та повного заповнення паливних баків або при грубій посадці, створюються умови значної витрати ресурсу силової конструкції планера і шасі літака, появи дефектів у вигляді тріщин втоми. Після фіксування таких перевищень вертикального навантаження у центрі мас $n_{y}$ доцільно провести цільовий огляд основних силових елементів планера і шасі літака, зокрема відповідний контроль 3’єднання кріплення консолей крила.

\section{Список літератури}

1. Юхачов В.В., Харченко О.В., Пащенко С.В., Хільченко М.Ф. Коливання і ресурс авіаційних конструкцій. Під ред. О.В.Харченка. - Одеса, 2010. - 128c.

2. Барзилович Е.Ю., Савенков М.В. Статистические методы оценки состояния авиационной техники. - М.: Транспорт, 1987. - $240 \mathrm{c.}$

3. Ильичев В.Д. Расчет текущего безопасного ресурса конструкции. Труды ЦАГИ, 1972. - Вып.1391. - 24 с.

4. Иосилевич Г.Б. Детали машин. - М.: Машиностроение, 1988. - 368 с.

5. Зайцев В.Н., Рудаков В.Л. Конструкция и прочность самолетов, К.: Вища школа, 1978. - 487 с. $470 \mathrm{c}$.

6. Гудков А.И., Лешаков П.С. Внешние нагрузки и прочность летательных аппаратов. - М.: Машиностроение, 1968. -

7. Райхер В.Л., Француз Т.А. Рекомендации ЦАГИ по способам расчета усталостных повреждений и оценки ресурса конструкции самолетов. - Отчет ЦАГИ, 1971. - № 711. - 22 с.

8. Райхер В.Л., Цымбалюк В.И., Лейбов В.Г. Рекомендации по способам расчета повторяемости нагрузок, усталостного повреждения и оценке ресурса конструкции самолета на этапе проектирования. - Труды ЦАГИ, 1974, вып. 1219. - 45 с.

9. Справочник по авиационным материалам. Том 1, Том 3,- М.: Машиностроение, 1965. - 365 с.

10. Панасюк В.В. Деякі актуальні проблеми міцності матеріалів і довговічності конструкцій - Фізико-хімічна механіка матеріалів // 2009. - №2. - С. 5-22.

11. Вапник В.Н., Червоенекис А.Я. Теория распознавания образов. - М.: Наука, 1974. - 416 с.

12. Вентцель Е.С. Теория вероятностей // 10-е издание. - М.: Высшая школа, 2006. -575 с.

Надійшла до редколегії 27.10.2021

Схвалена до друку 28.11.2021

\section{Відомості про авторів:}

\section{Ковель Петро Петрович}

кандидат технічних наук

провідний науковий співробітник

Державного науково-дослідного інституту авіації,

Київ, Україна

peter.kovel@gmail.com

https://orcid.org/0000-0003-3099-4467

\section{Карпенко Олександр Валерійович}

начальник науково-дослідної лабораторії

Державного науково-дослідного інституту авіації,

Київ, Україна

mail.oleksandr@gmail.com

https://orcid.org/0000-0002-9507-3573

\section{Information about the authors:}

\section{Petro Kovel}

Candidate of Technical Sciences

Leading researcher

of State Research Institute of Aviation,

Kyiv, Ukraine

peter.kovel@gmail.com

https://orcid.org/0000-0003-3099-4467

\section{Oleksandr Karpenko}

Head of Research Laboratory

of State Research Institute of Aviation,

Kyiv, Ukraine

mail.oleksandr@gmail.com

https://orcid.org/0000-0002-9507-3573 


\section{Стрєла Максим Сергійович}

науковий співробітник

Державного науково-дослідного інституту авіації, Київ, Україна

maxim.strela1991@gmail.com

https://orcid.org/0000-0003-4055-1600

\section{Maxim Strela}

Researcher Associate of State Research Institute of Aviation, Kyiv, Ukraine maxim.strela1991@gmail.com https://orcid.org/0000-0003-4055-1600

\title{
ANALYSIS OF THE EXHAUSTION RATE OF RESOURCE INDICATORS OF POWER ELEMENTS OF IL-76 AIRCRAFT ACCORDING TO THE ACTUAL LOAD OF POWER STRUCTURE
}

\author{
P. Kovel, O. Karpenko, M. Strela
}

Many leading specialists of aircraft design bureaus and industry research institutions still not consider individual (detailed) calculations of the durability of the main power structure elements of the aircraft on fatigue a mandatory element of working design. Until now, there is an opinion in the industry that field tests on fatigue of structural elements and glider units "by themselves" will reveal all potentially critical zones of structural elements and will allow to obtain an experimental assessment of the durability of these zones on fatigue. Therefore, full-scale calculations of the durability of individual structural elements of the aircraft on fatigue is practically not required, there is no special need for methods of such calculations. The consequence of such a policy was a clear lag in domestic industry methods for calculating the durability of elements of aircraft structures on fatigue from foreign ones.

Without diminishing the importance of field tests on the fatigue of the entire aircraft, the authors believe that this attitude to individual (detailed) calculations of durability on fatigue is a systemic error that has already led to the design of aircraft with serious shortcomings that directly affect safety and cost-effectiveness aircraft. These shortcomings are usually detected during the period of intensive operation of the entire fleet of aircraft, so field tests for fatigue of glider units (or glider as a whole) in practice are carried out for a long time, and the amount of fatigue tests of individual designs is limited.

The need for individual (detailed) calculations of the durability of the elements of the main power structure on fatigue, in particular the wings of the aircraft, to extend the operation of aircraft type IL-76 is obvious. Such studies make it possible to reasonably approach the choice of material, stresses, design and technological solutions of power elements, to ensure the optimal ratio between the durability of the structure on fatigue and economic efficiency of the aircraft as a whole.

Keywords: fatigue strength, relative damage at fatigue, resource consumption equivalent, resource consumption coefficient, operation according to technical condition. 